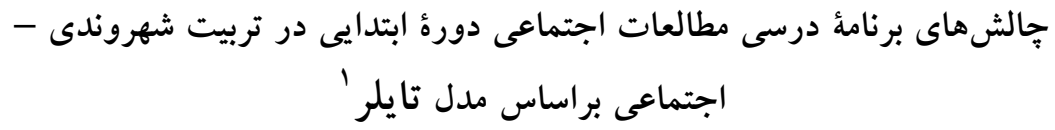

\title{
The Challenges of Social Sciences Curriculum in Primary School Regarding Citizenship-Social Education based on Tyler Model
}

\section{R. Fozoni Shirje, M. Piri (Ph. D), S. Asadiyan (Ph. D)}

Abstract: This study has been conducted about one of the fundamental debates in educational system and curriculum development titled "socialcitizenship training". The methodology was survey study and the sampling population was 337 (61 male- 276 female) elementary school teachers in Tabriz which were selected on the basis of multi-staged and comparative cluster sampling. For data analysis the Freidman and $\mathrm{T}$ tests were used. The findings showed that in the "goals" stage, the failure of the goals of citizenship training in establishing an effective relationship between schools and other organizations; In "content" stage, the negligence of modulation of concepts and skills of citizenship in different zones of learning; in"teaching and learning" stage, lack of appropriate activities and in"evaluation"stage, overlooking the creativity and innovation of learners were among the most significant challenges. Meanwhile, the result of the independent $T$ test showed that there was a meaningful difference between the views of female and male teachers on"content", "learning and teaching activities" and "evaluation"stages. However, in "goal" stage there was no meaningful difference.

Key Words: Citizenship education, Social studies, Curriculum, Teachers..

$$
\begin{aligned}
& \text { رضا فزونى شرهجينى '، دكتر موسى ييرى'، }
\end{aligned}
$$

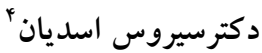

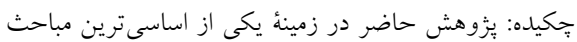

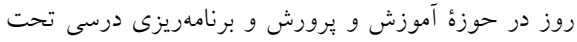

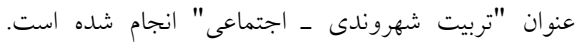

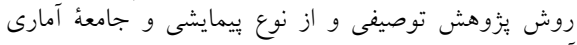

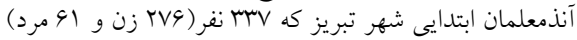

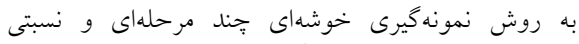

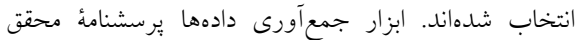

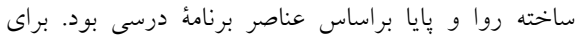

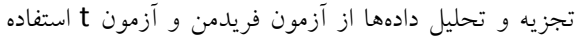

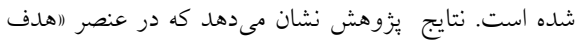

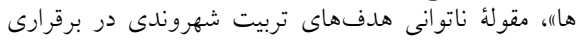

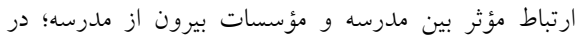

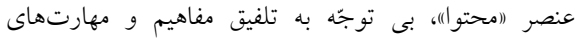

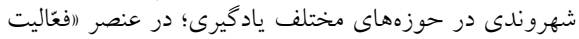

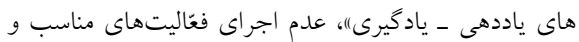

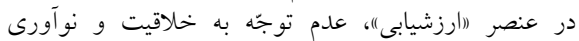

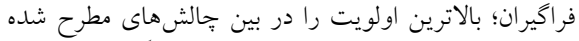

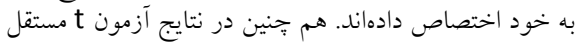

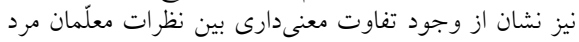

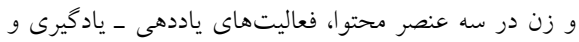

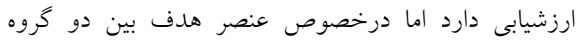

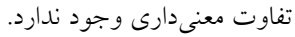

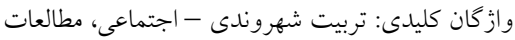

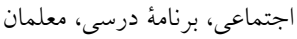

\footnotetext{
'ا اين مقاله برگرفته از باياننامهُ كارشناسى ارشد با همين عنوان مىباشد كه در دانشخاه شهيد مدنى آذربايجان انجام

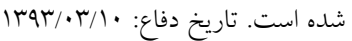

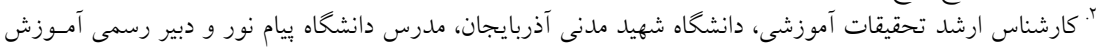

و يرورش)

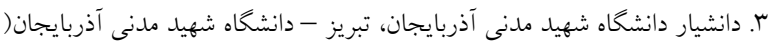
.Piri_moosa@Yahoo.com
} †. استاديار دانشگاه شهيد مدنى آذربايجان (Pazhohesh_Phd@Yahoo.com). 


\section{مقدمه و بيان مسئله}

براى علماى تربيت روشن است كه مدرسه يك نهاد اجتماعى است كه در تكوين

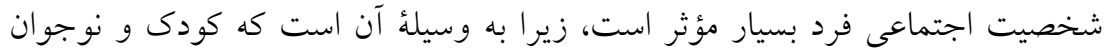

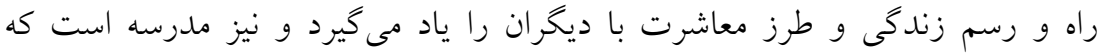

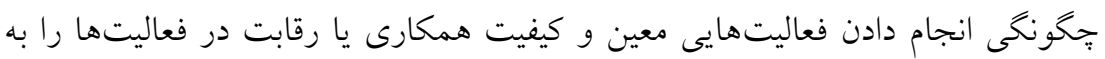

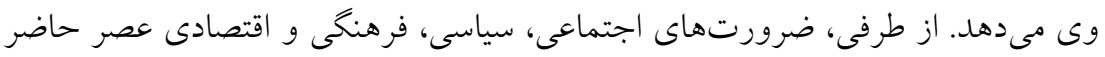

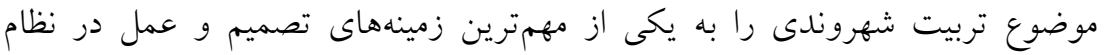

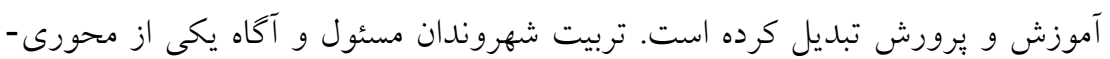

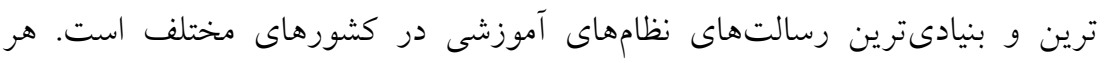

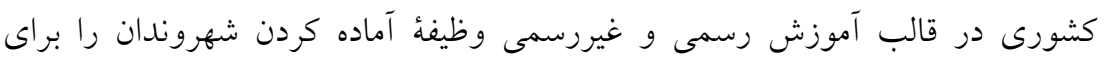

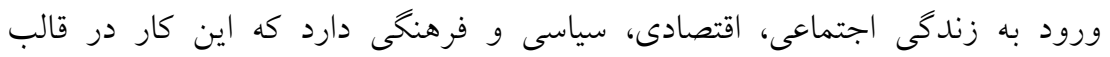

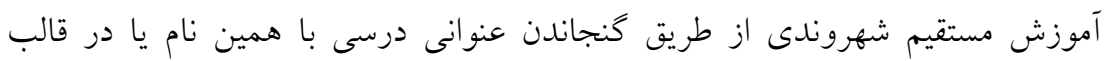

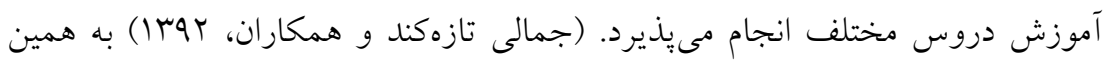

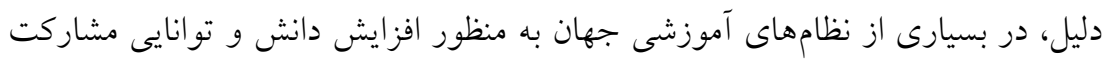

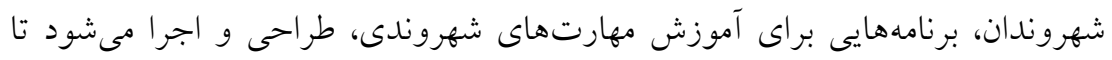

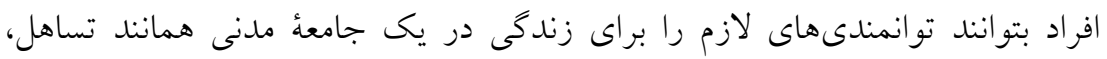

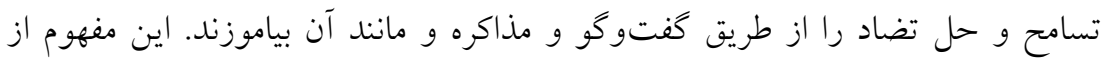
طريق توجه به مقوله تربيت شهروندى در برنامهاى درسى و نظام آموزشى امكان

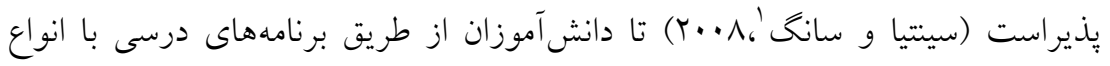
دانش علمى، اجتماعى، تاريخى، اقتصادى و سياسى، مهارتها و نغخرش هاى مختلفى هم

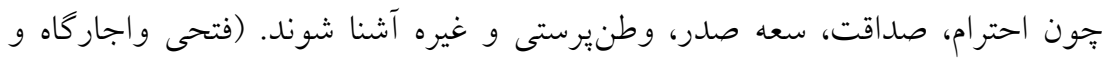

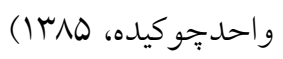

1- Cynthia \& Sung 
جالش هاى برنامة درسى مطالعات اجتماعى ...

از ميان تمام موسسات دخيل در تربيت شهروندان، مدارس و برنامههاى درسى آن-

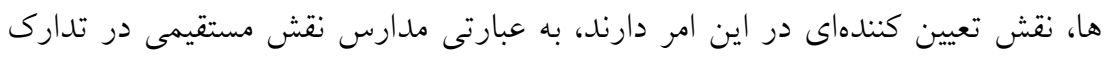

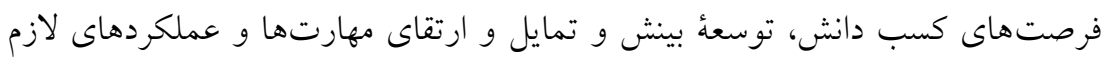

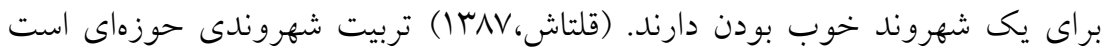

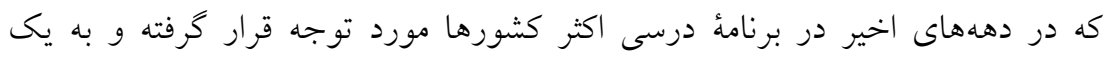

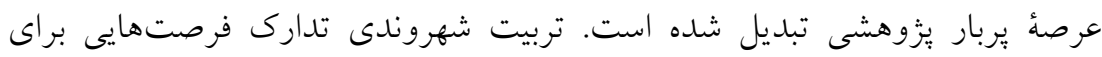

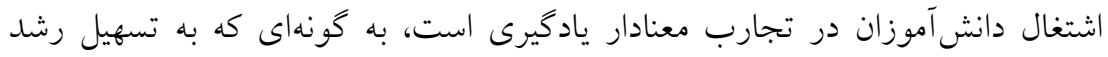

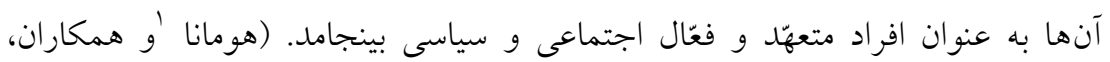

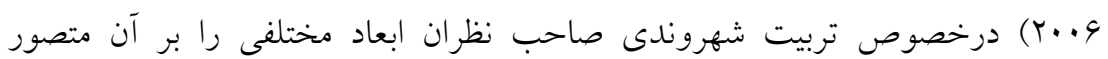

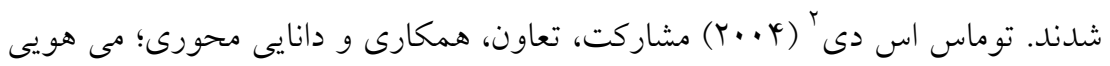

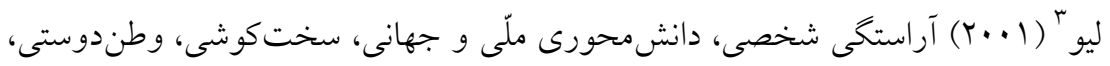

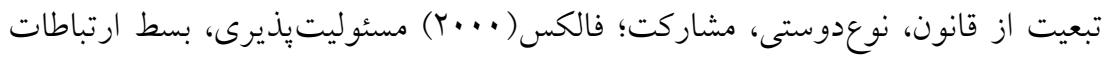

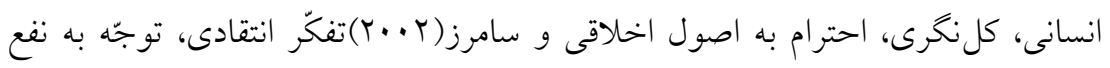

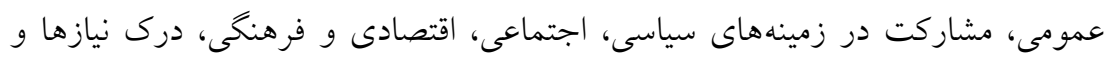

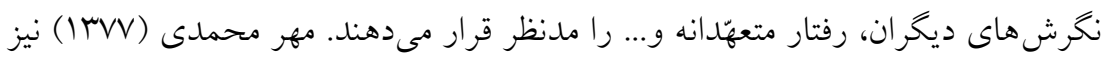

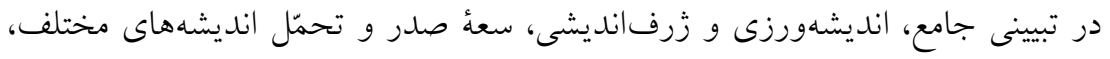

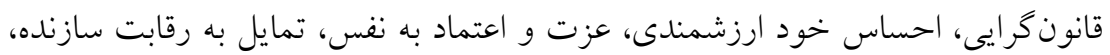

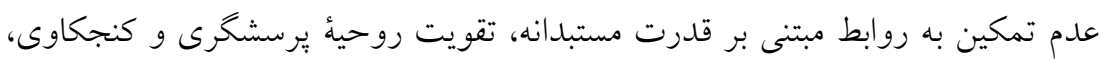

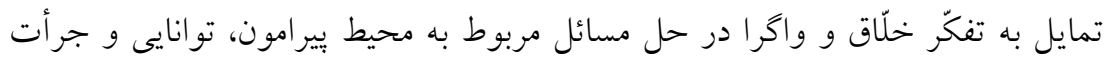

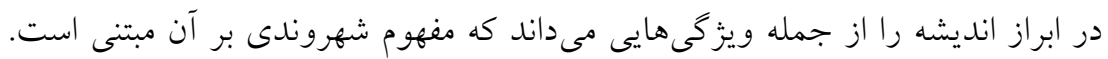

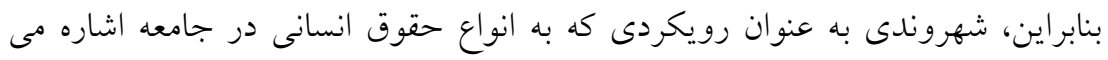

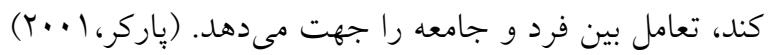

2- Humana

3- Tomas s Dee

4- Mei Hui Liu 
امروزه جامعلة محلى، ملى و جهـانى نيازمنــ حضـور انسـانهـايى آخَاه، مســول، مشاركتجو، حساس به مسائل جامعه و علاقمند به تعامل و كفتكو است. لذا بايد تعليم

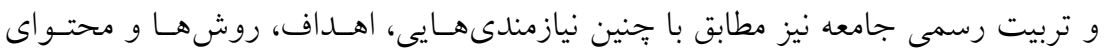

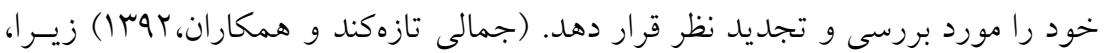

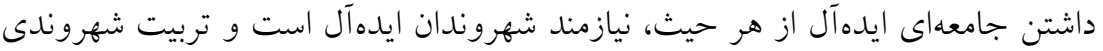

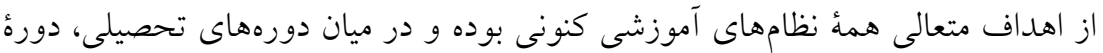

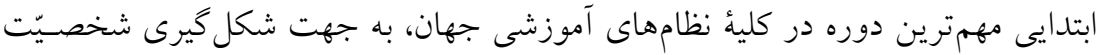

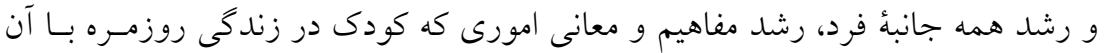

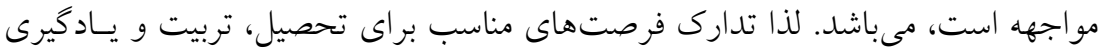

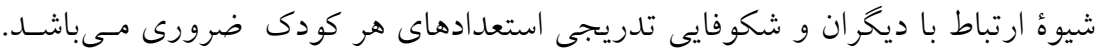

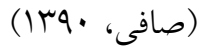
از آن جايى كه در نظام آموزشى ايران، در دوره ابتدايى كتاب درسسى معينى تحـت

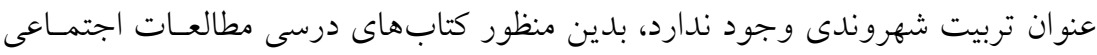

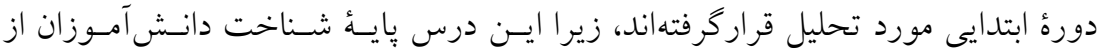

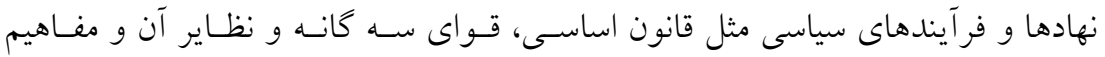

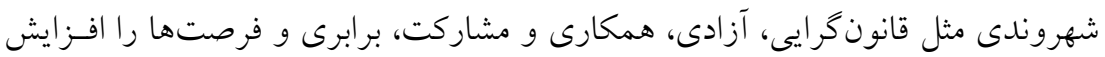

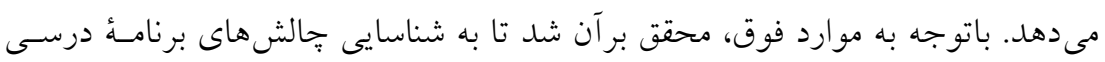
مطالعات اجتماعى دورة ابتدايى در تربيت شهروندى ـ اجتماعى بيردازد .

\section{مبانى نظرى و وييشينهُ يزوهش}

شهروندى ازجمله مباحث مهم درحوزه مطالعات اجتماعى، سياسى و تربيتى است. اين

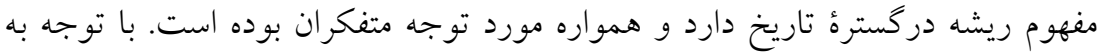

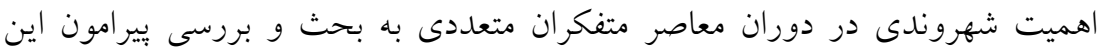

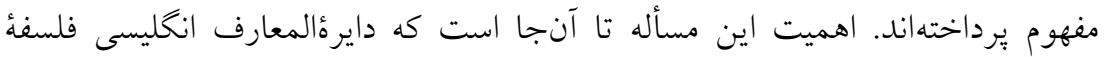

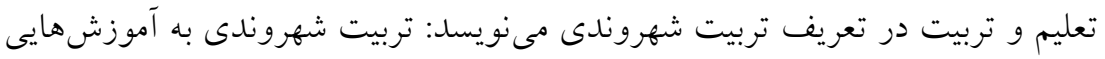


جالش هاى برنامة درسى مطالعات اجتماعى ...

اطلاق مى گردد كه به توسعهُ شهروندى يا توانمندىهاى شهرى مربوط مىشود و اهداف

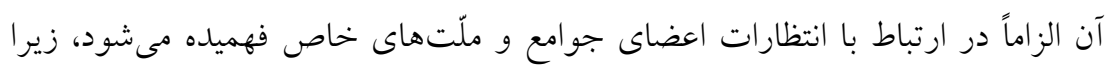

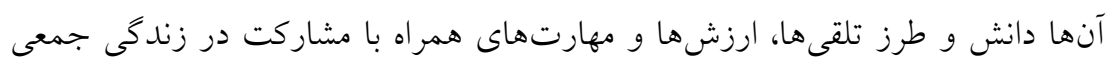

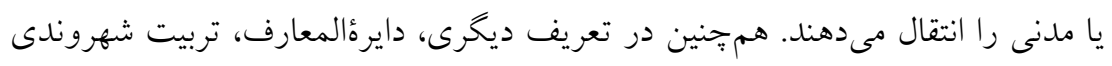

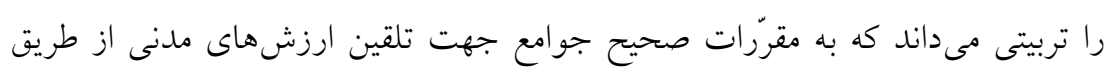

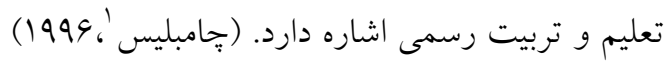

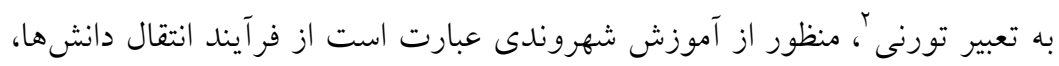
ارزشها و نكرش هاى لازم براى مشاركت و ثبات سياسى جامعه از نسلى به نسل دئل ديخر.

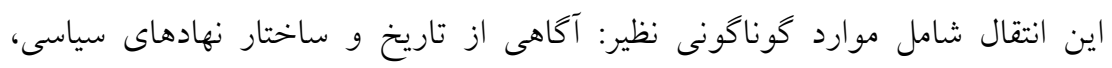

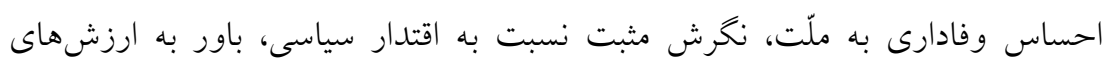

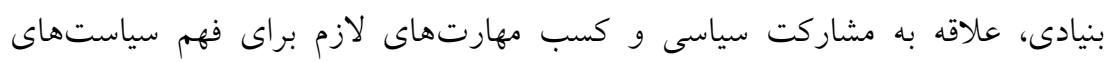

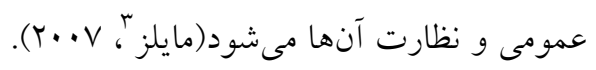

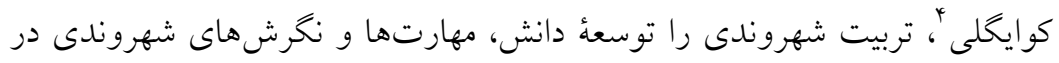

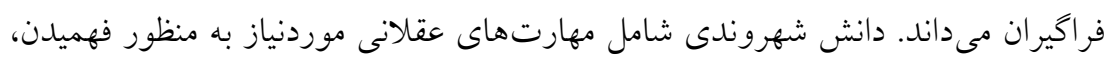

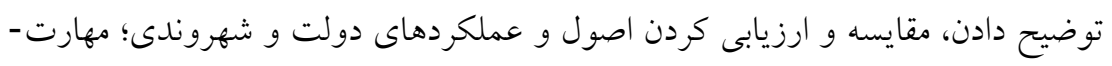

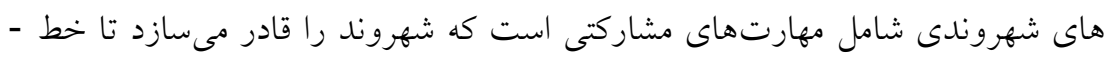

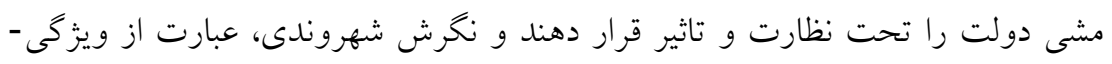

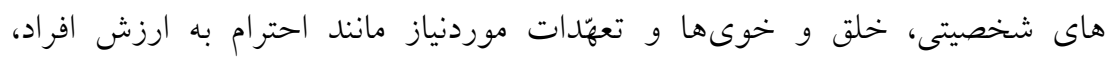

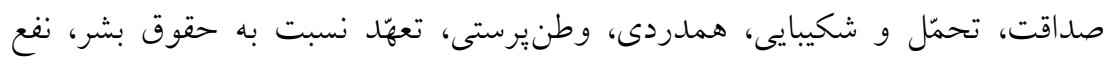

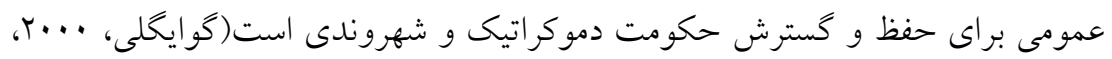

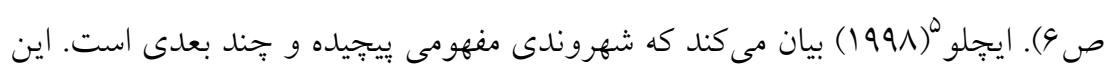

1- Chombliss

2-Torney

1-Miles

2- Quigly

3- Ichelo 
مفهوم مشتمل بر ابعاد قانونى، فرهنكى، اجتماعى و سياسى است و حقوق و الزامات،

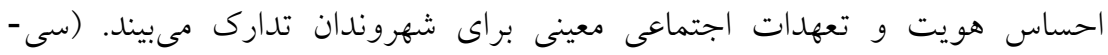

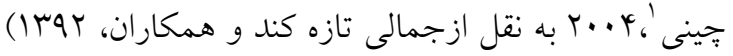

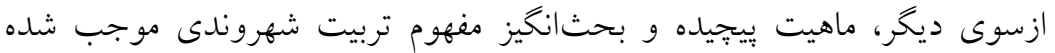

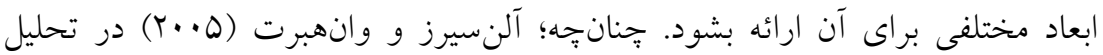

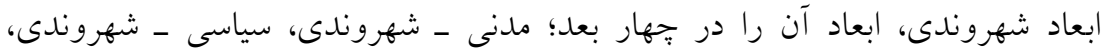

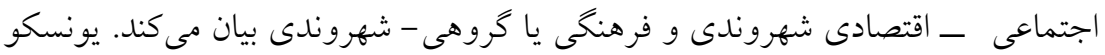

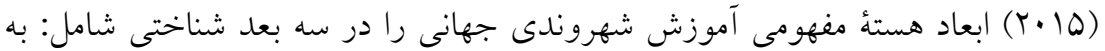
دست آوردن دانش، درك و تفكر انتقادى در موارد جهانى، منطقهاى، مسائل ملى و

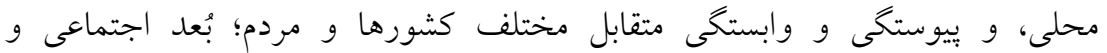

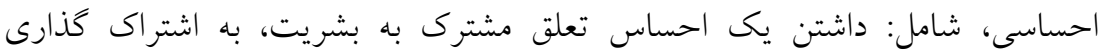

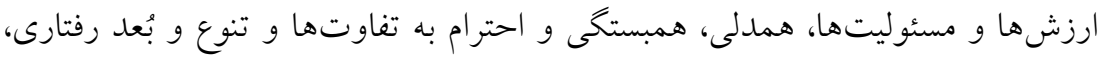
شامل: عملكرد موثر و مسئولانه در سطوح محلى، ملى و جهانى براى ساختن جهان

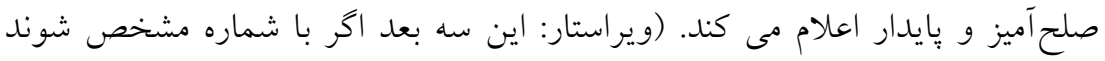

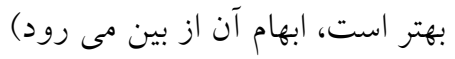
بنابراين، هركشورى در قالب تعليم و تربيت رسمى و غيررسمى، وظيفهُ آماده كردن

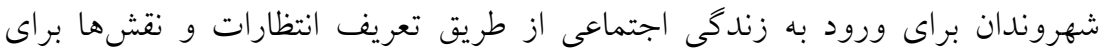

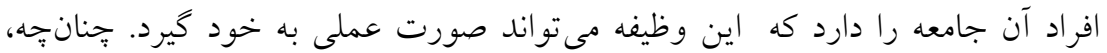
يكى شهروند مطلوب براى جامعه ايران بايد در سه حيطه يا قلمرو داراى صلاحيتهاى معينى باشد كه عبارتند از:

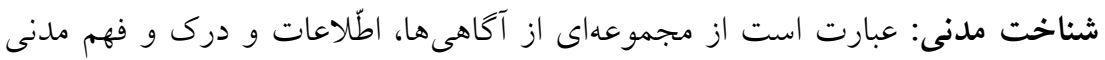

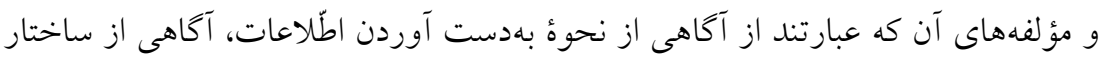

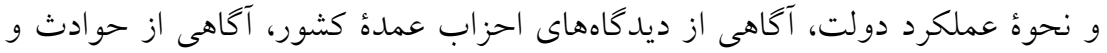

4- Cecchini 
جالش هاى برنامة درسى مطالعات اجتماعى ... - ج

رويدادهاى جامعه، آكاهى از قوانين و مقررات اجتماعى و آكاهى از حقوق شخصى و بين المللى. توانايى مدنى: عبارت است از مجموعهاى از مهارتها، قابليتها و توانمندىهايى كه هر فرد براى زيست در جامعهاى كه در آن زندكى مى كند به آنها نياز دارد و مؤلفههاى آن عبارتند از توانايى مشاركت با ديخران، توانايى انجام امور بدون اتكا به ديخران، توانايى اتخاذ تصميمات منطقى و توانايى رفتار بر اساس اصول اخلاقى و مذهبى مطلوب.

نخرش مدنى: كه عبارت است از مجموعهاى از طرز تلقىها، باورها و ديدكاههايى كه براى يك شهروند خوب ضرورى است و مؤلفههاى آن عبارتند از يذيرش تنوع و تكثر در جامعه، و احترام به آن، داشتن اعتقادات و باورهاى مستقل، داشتن روحئُ مسئوليتيذيرى، دارا بودن حس وطنيرستى، داشتن روحية بردبارى و تحمل، داشتن روحيئ انتقاديذيرى، دارا بودن روحية قدرشناسى نسبت به ميراث فرهنكى و هويت مذهبى

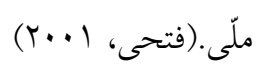
مدرسه به عنوان بخشى از آموزشىويرورش رسمى براى آمادهسازى افراد بـهـ منظـور

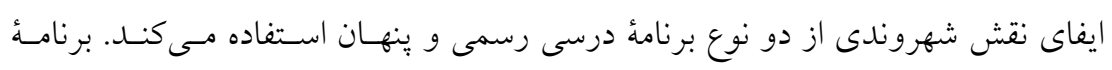
درسى رسمى حاوى هدفها، محتوا و روشهاى آشكارى است كه منتشر شده و مـورد

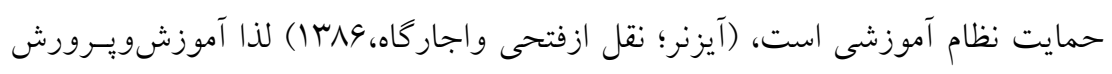

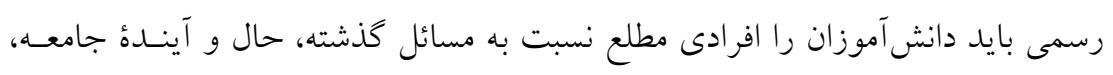
محيطزندكى(اعم از طبيعى و اجتماعى)، متعهّد به ارزش ها و علاقهمند بـه مشـاركت در فعّاليّتهاى اجتماعى، سياسى و داشتن روحيذُ انتقاديذيرى و انتقادكنندكى تربيـت كنـد.

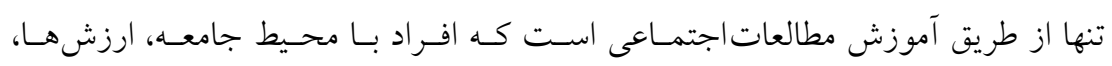
فر آيندهاى اجتماعى و اقتصادى و مسئوليّتهاى خود نسبت به ديخران آشنا مسىشـوند.

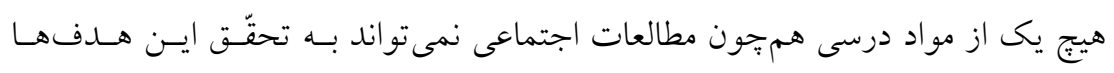
كمك كند(فلاحيان و همكاران، الوس (1). 
اهمّيت آموزش مطالعات اجتماعى وقتى بهتر مشخص مىشود كـه نابهنجـارىهـاى

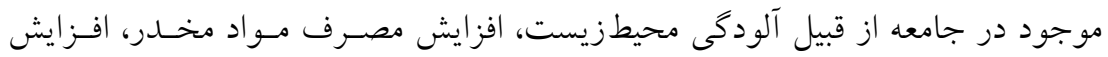

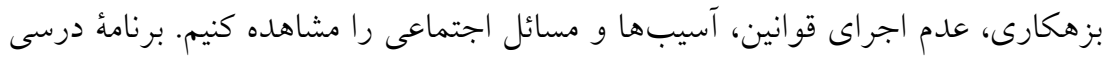

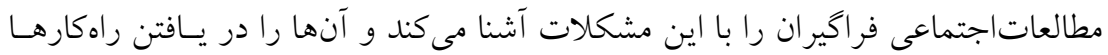

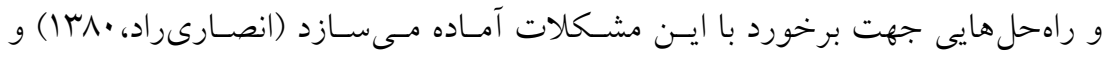
دانش آموزان را به عنوان شهروندان مفيد در جامعهد آماده مى كند.

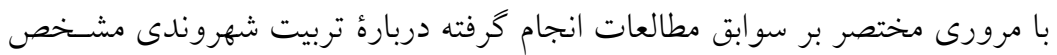

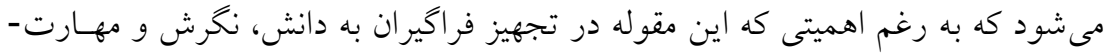

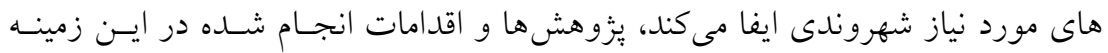

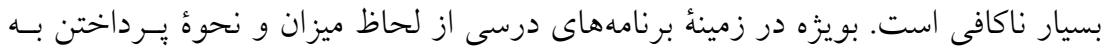
مؤلفههاى شهروندى يزوهششهاى اندكى صورت كرفته است.

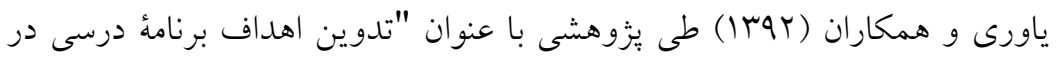

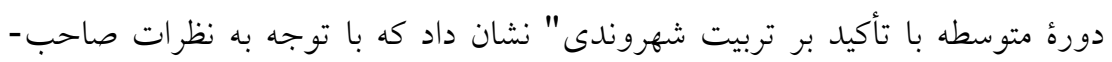

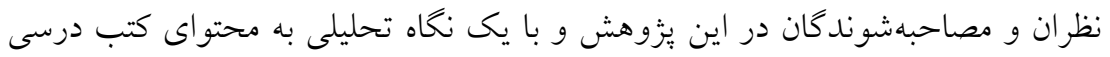

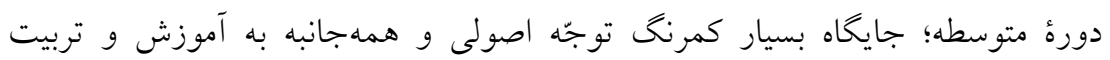

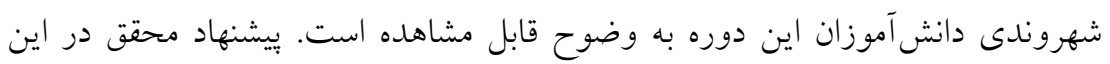

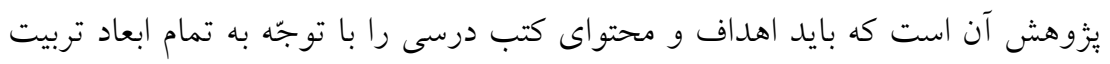
شهروندى تهيه و تدوين شود و به صورت مستمر در فاصله هاى زمانى ارزيابى كردد.

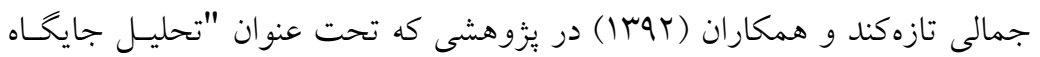

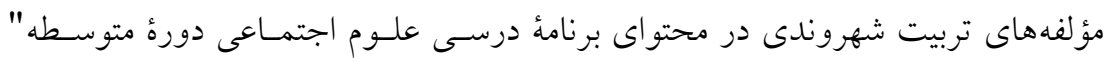

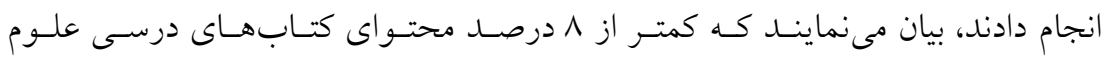

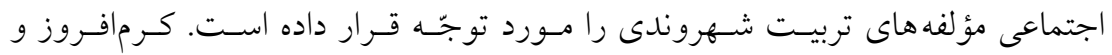

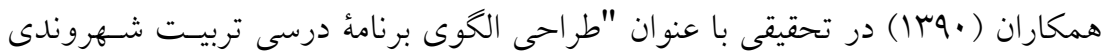

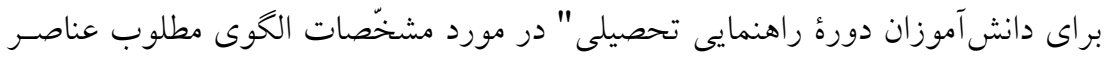

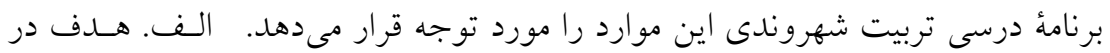


جالش هاى برنامة درسى مطالعات اجتماعى ... - ج

قالب فعاليت شاكردان و بيشتر جنبه عملكردى داشته باشد. ب. در مورد روش تدريس، ايفاى نقش، تفحّص گروهى، يادگيرى كنترل خود، حل مسئله، تعامل و كـار در خـروههاى كوجّك. ج. در رويكردهاى سازماندهى عمدتاً تأكيد بر رويكرد تلفيقى است كه به و احدهاى درسى ميان رشتهاى، الكوى روز تلفيقشده، تلفيق مهارتهـا و فر آينـدها و ... اشاره دارد. د. روش هاى ارزشيابى مناسب نيز عمدتاً معطوف به روشهاى انـدازه خيـرى بازدههاى روانى ـ ـ حركتى و عاطفى است كه شامل آزمسون كتبـى عملكــدىى، آزمسون شناسايى، انجام عملكرد در موقعيّتهاى شبيهسازى شده، فهرست وارسى، واقعهنخـارى و.... ( - n است.

مجلل جوبقلو (INVV) طى يزوهشى با عنوان "تحليل برنامه درسى اجرا شدهُ مقطع ابتدايى نظام آموزشى ايران از بعد تربيت شهروندى" نشان داد كه برنامة درسى تربيت شهروندى موجود و اجرا شده در مدارس ابتدايى مطلوب نبوده و قادر به شكلدهى رفتار مطلوب شهروندى در دانشآموزان مقطع ابتدايى نيست.

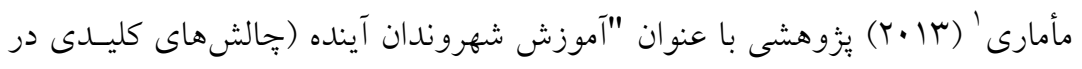
كشورهاى عربى)" در جستوجوى ايجاد بحث و كفت و گــو بـراى قـدم برداشـتن در جهت تقويت آموزش شهروندى در جهـان عـرب بـا هـدف تـأثيرات ايسن مباحسث در تدريس و آموزش انجام داد. نتايج نشانكر عدم وجود يك برداشـت مشـترك از مفهـوم شهروندى، جالشهاى خاصى را در آموزش شهروندى ايسن كشـورها بـه وجــود آورده است. يافتهُ دوم اين يزوهش حاكى از آن است كه آموزش شهروندى نه تنها در مدارس بلكه بايستى در فضاى بيرون از مدرسه (كه شامل دركير كردن والدين به عنوان اعضـاى اصلى جامعه) نيز بايد وجود داشته باشد. همجهنين، مطالب موجود در مراكز تربيت معلّم نسبت به آموزش و تربيت شهروندى بايستى تغيير كند تا ديد گاه معلّمان نيز تغيير يابد.

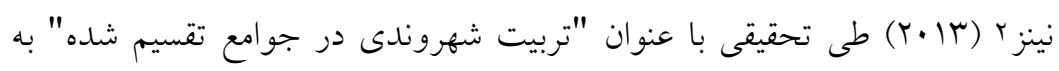
بررسى ديدكاه و درك معلّمان ايرلند شمالى از آموزش شهروندى در جوامع تقسيم شده

1-Maamari

2- Nines 
و انعكاس آن در كفتمانهاى شهروندى مى يردازد. يافتهها نشان مىدهد كه طبيعت

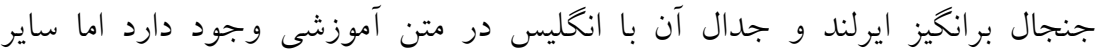
شاخصهاى محروم كننده مثل نزاد و جنسيت در بيى يافتن جايى در متن آموزشى و

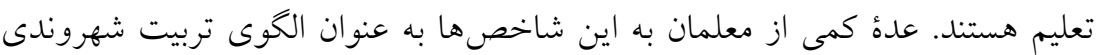

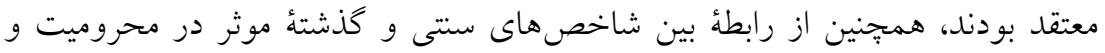

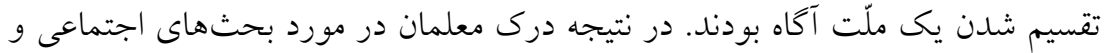

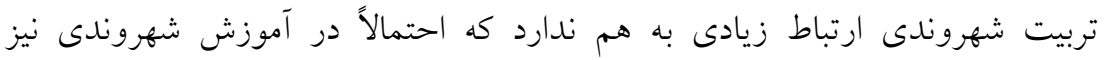

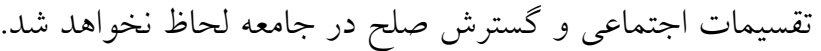

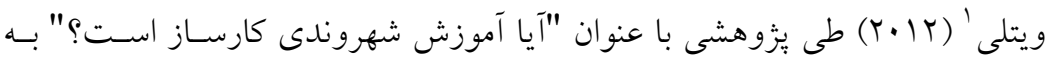

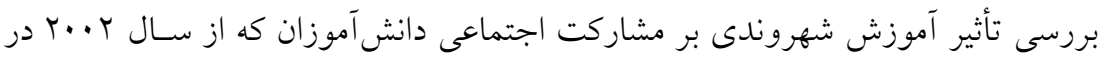

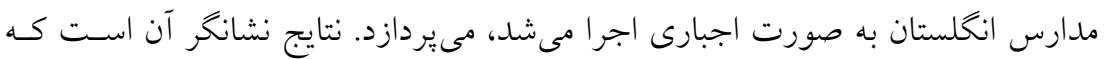

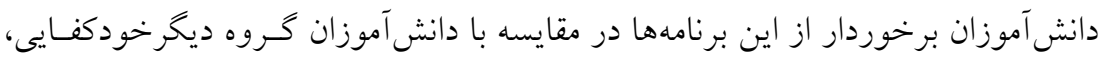
دانش سياسى و مشاركت سياسى و اجتماعى بالايى دارند.

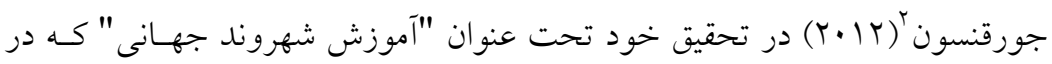

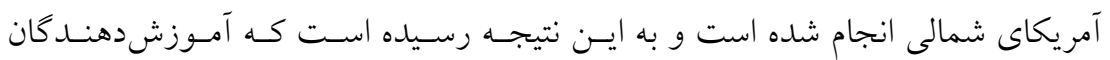

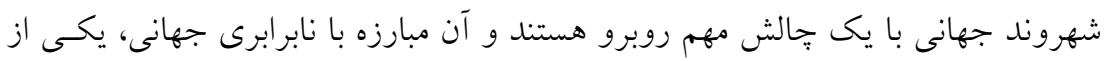
عواقب استعمار و ايدئولوزىهايى كه از حقوق اقليت در برابر اكثريت حمايت مى كنــد،

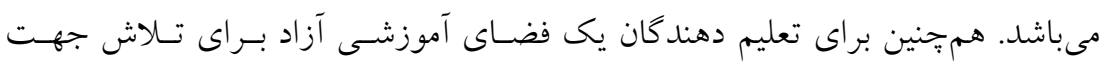

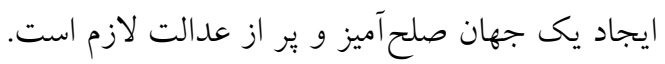

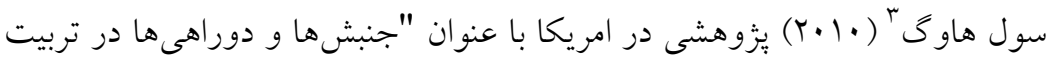

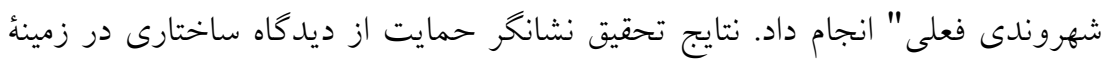

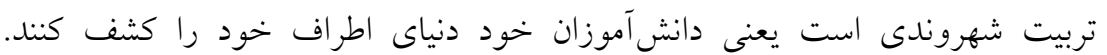


جالش هاى برنامة درسى مطالعات اجتماعى ... - ج

همجنين بايستى مفهوم شهروندى با توجه به اينكه ايدئولوزيك و سياسى است بايد به صورت خاص در هر منطقه و كشور تدريس شود.

\section{مدل مفهومى تحقيق}

به طور كلى با توجه به ادبيات مربوط به موضوع تحقيق و ابعاد تربيت شهروندى مطرح شده از سوى متخصصان، مؤلفههاى تربيت شهروندى - اجتماعى شامل: مشاركت، خلاقيت، تفكّر انتقادى، احترام به يكديخر و مذاكره و تعاملات و عناصر برنامئ درسى مطالعات اجتماعى براساس مدل تايلر؛ شامل: اهداف، محتوا، فعّاليتهاى ياددهى يادكيرى و ارزشيابى بوده كه اين مؤلفهها با استناد به بزوهشهاى داخلى و خارجى مرتبط با موضوع تحقيق به دست آمده است كه مبانى اصلى يزٔوهش حاضر نيز به شمار مى آيد كه درقالب الكوى مفهومى ذيل نمايش داده شده است.

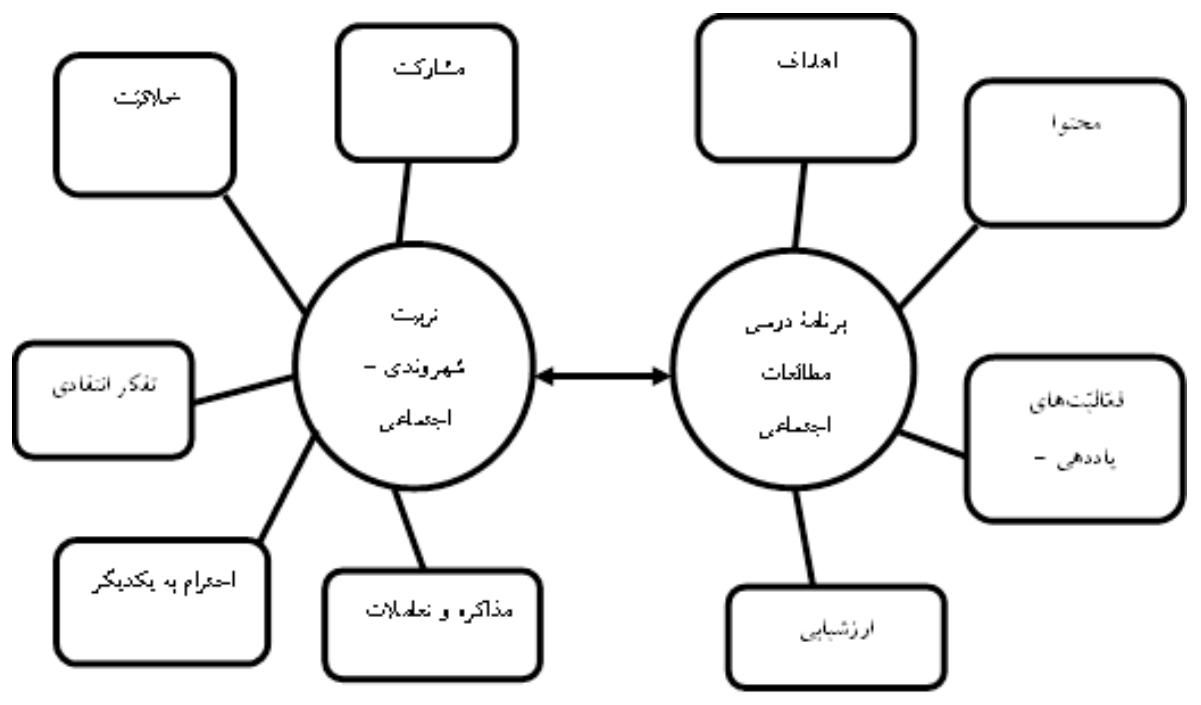

شكل ا: مدل مفهومى تحقيق 
هدف كلى يثزوهش شناسايى جالش هاى برنامة درسى مطالعات اجتماعى دورة ابتدايى در تربيت شهروندى سرى

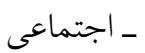
سوال هاى يزوهش ا. مهمترين جالشهاى اهداف مطالعات اجتماعى دورة ابتدايى از بعد تربيت شهروندى

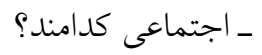
ז. مهمترين جالشهاى محتواى مطالعات اجتماعى دورة ابتدايى از بعد تربيت شهروندى - اجتماعى كدامند؟ r. مهمترين خالشهاى فعاليتهاى ياددهى - يادگيرى مطالعات اجتماعى دورة ابتدايى

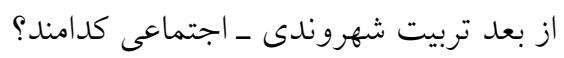

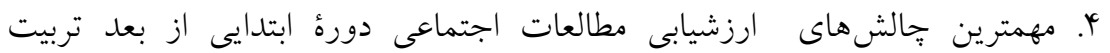

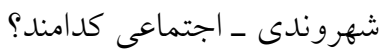
ه. آيا نظرات معلّمان زن و مرد در مورد جالشهاى هداى برنامة درسى مطالعات اجتماعى

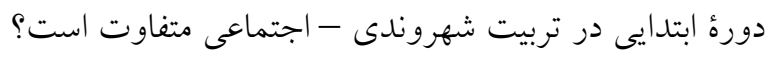

روش يُوهش

باتوجه به هدف يزوهش، روش يُزوهش توصيفى و از نوع بيمايشى بوده است. جامعذ

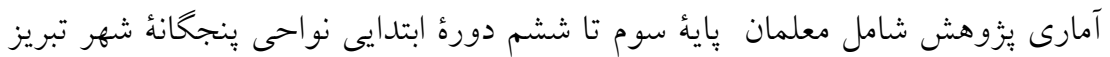

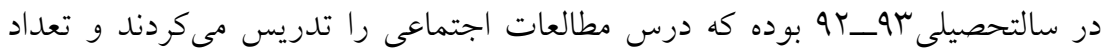

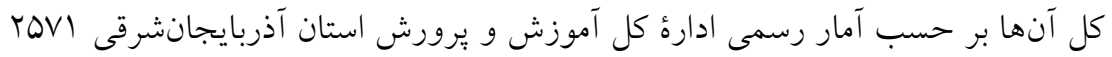

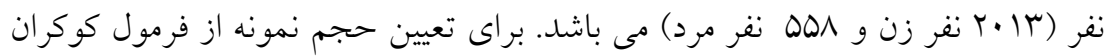

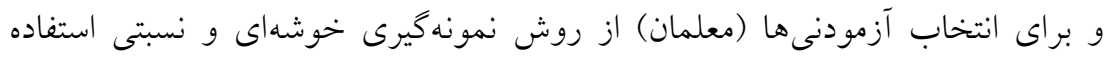

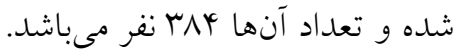


جالش هاى برنامة درسى مطالعات اجتماعى ...

$n=\frac{\mathrm{z}^{\Uparrow} \mathrm{pqN}}{\mathrm{d}^{\gamma}(\mathrm{N}-1)+\mathrm{z}^{\gamma} \mathrm{pq}}$

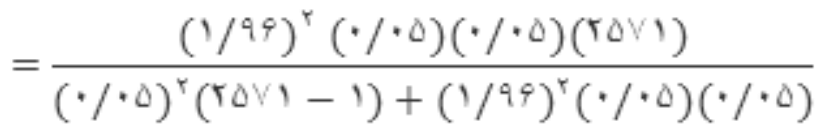

$$
\begin{aligned}
& =\frac{r 489 / 1}{8 / 454} \simeq \mathrm{rg}
\end{aligned}
$$

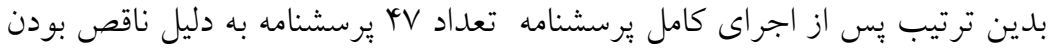

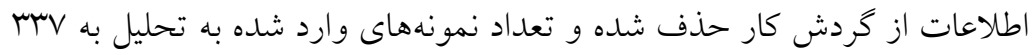
نمونه(نفر) كاهش يافت.

در يُزوهش حاضر براى جمع آورى داده ها از برسشنامهُ محقّق ساخته اسـتفاده شـــه

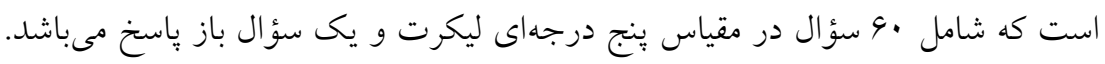

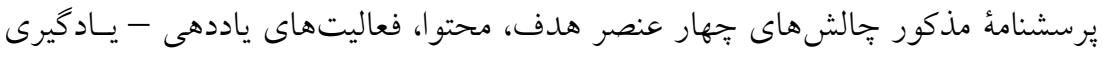

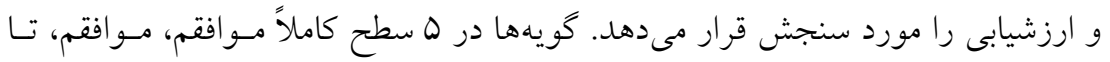

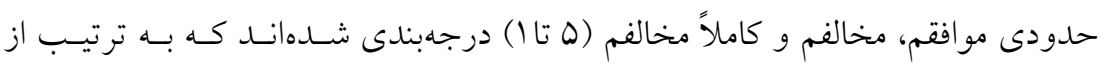

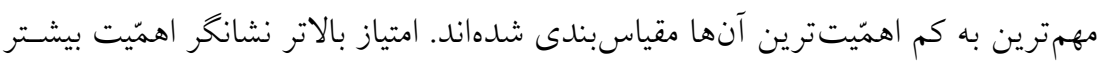

به منظور بررسى دقت و صحت سؤالها و گويههاى بهكار رفته در برسشنامه روايى

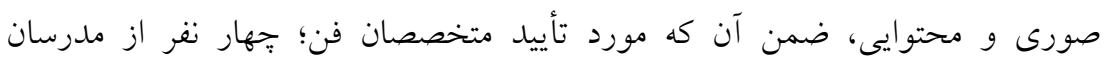

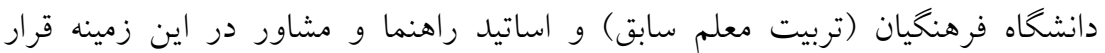

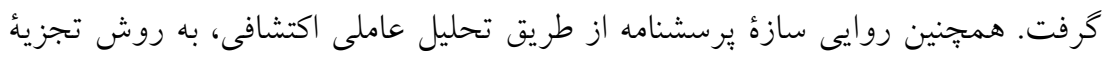

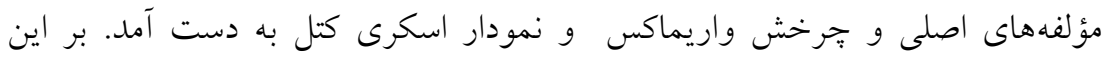

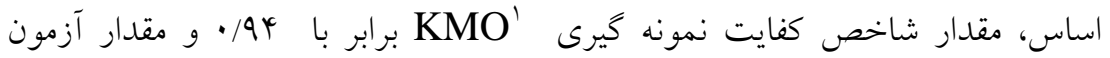

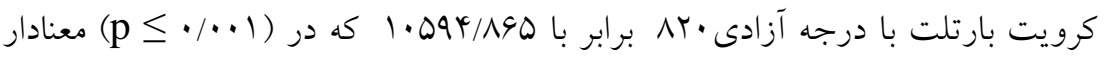

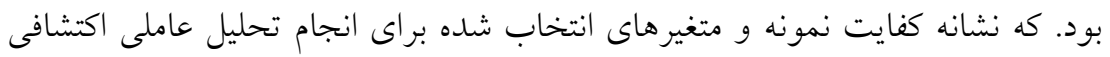

1- Kaiser Meyer Olkin(KMO) 
است. نتايج تحليل عاملى به روش مؤلفههاى اصلى با جرخش واريماكس' و حذف

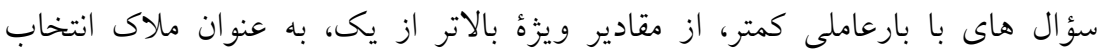

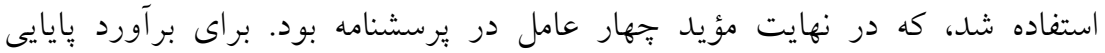

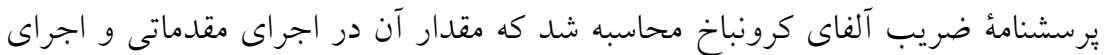
كامل درجدول ا ارائه شده و همه ضرايب بيش از •V/· • ، كه نشان دهنده بِايايى قابل قبول ابزار بوده و تأكيد بر همسانى درونى ابزار اندازه خيرى دارد. جدول ا ضريب الفاى كرونباخ هريك از مؤلفهها

\begin{tabular}{|c|c|c|c|c|}
\hline \multicolumn{2}{|c|}{ بعد از اجراى كامل و تحليل عاملى اكتشافى } & \multicolumn{2}{|c|}{ اجراى مقدماتى } & \multirow[b]{2}{*}{ مؤلفه } \\
\hline تعداد گويه & ضريب الفاى & تعداد گويه & ضر كريب الفاى & \\
\hline 10 &.$/ 94$ & IV &.$/ 94$ & هدفها \\
\hline 11 &.$/ 9 Y$ & IV &.$/ 9 Y$ & محتوا \\
\hline$\wedge$ & $\cdot / \Lambda 1$ & if & •/Ar & فعّاليتهاى ياددهى \\
\hline$v$ & $\cdot / 19$ & ir & $\cdot / \mathrm{V} \Lambda$ & ارزشيابى \\
\hline 41 & $\cdot / 9 V$ & 4. & $\cdot / 94$ & كل \\
\hline
\end{tabular}

در اين يزووهش، دادههاى جمع آورى شده با استفاده از نـرم افزار 19

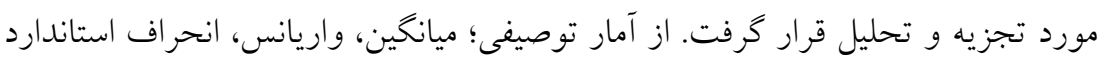

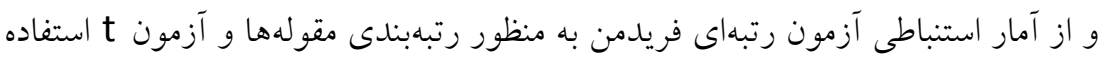
شده است.

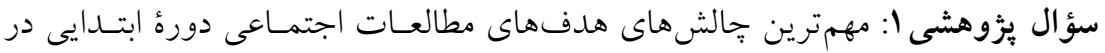
تربيت شهروندى - اجتماعى كدامند؟ 
جالش هاى برنامة درسى مطالعات اجتماعى ... - ج

جدول ب: نتايج آزمون فريدمن در خصوص اولويتبندى مقوله هاى هدفها براساس ياسخ معلمان

\begin{tabular}{|c|c|c|c|c|c|c|}
\hline مقد دود & 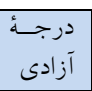 & تعداد & 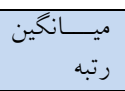 & سؤال & مقولههاى هدفها & 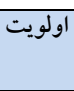 \\
\hline \multirow[t]{15}{*}{$14 V / 99}$. & \multirow[t]{15}{*}{14} & \multirow[t]{15}{*}{ mrv } & $\Lambda / v q$ & Q. & مؤستواتى در برقرارى ارتباط مؤثر بين مدرسه و & 1 \\
\hline & & & $\Lambda / V V$ & r & عدم توجه به شايستكى هاى اجتماعى & r \\
\hline & & & $N / D 1$ & 1 & 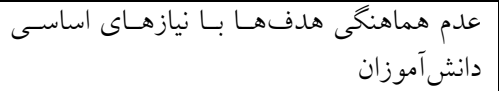 & $r$ \\
\hline & & & $1 / 49$ & m & 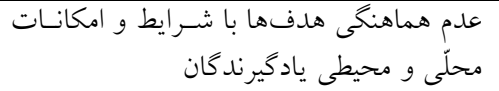 & r \\
\hline & & & N/ro & ro & عدم توجه به تفاوتهاى فردى دانشآموزان & 0 \\
\hline & & & N/TG & rv & 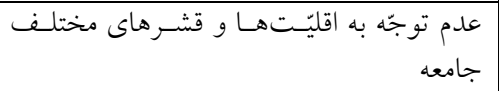 & 4 \\
\hline & & & N/Tr & 4. & انعطاف نايذيرى(تغيير نايذيرى) هدفها & $\mathrm{V}$ \\
\hline & & & N/Tr & or & 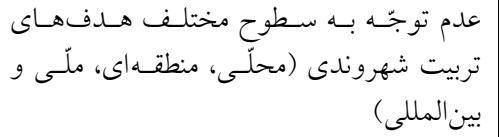 & V \\
\hline & & & $1 / 11$ & rr & 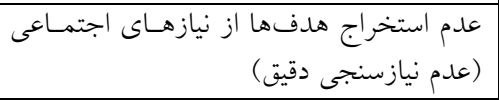 & $\wedge$ \\
\hline & & & N/l. & 11 & 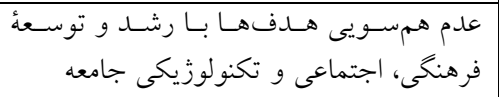 & 9 \\
\hline & & & $\mathrm{V} / \wedge \mathrm{q}$ & $\Delta \wedge$ & 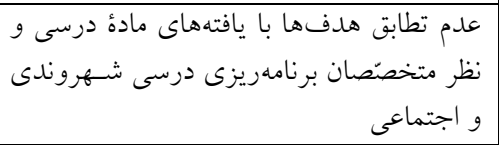 & 1. \\
\hline & & & $\mathrm{V} / \mathrm{VA}$ & 49 & 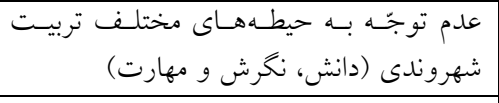 & 11 \\
\hline & & & $9 / 90$ & rq & 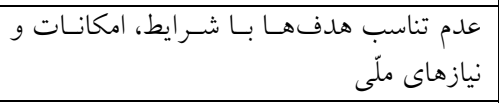 & IT \\
\hline & & & $9 / \Lambda$ & r9 & عدم همسويى هدفها با آرمانهاى جامعه & ir \\
\hline & & & $9 / \mathrm{NV}$ & 4. & عدم تطابق با ارزش هاى رايج جامعه & 14 \\
\hline & & & & & سطح معنى & \\
\hline
\end{tabular}


جدول ب نتايج آزمون فريدمن براى اولويتبندى كويههاى مربوط به مؤلفهُ (إجالشهـاى

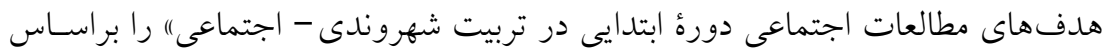

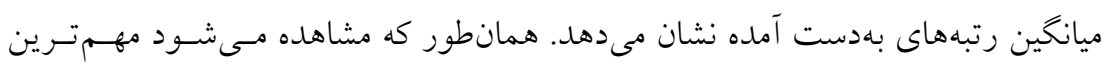

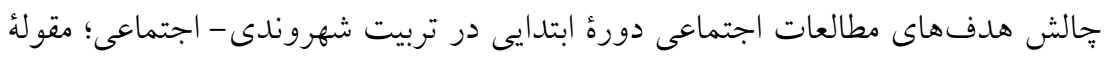

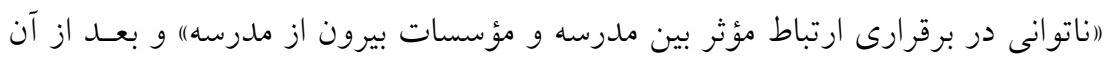

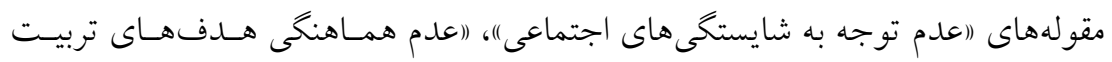

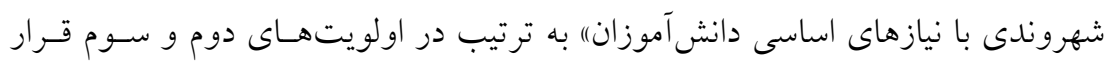
دارند.

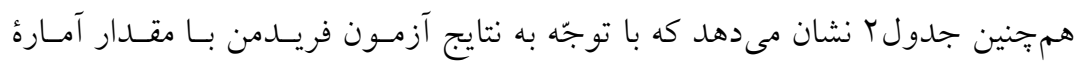

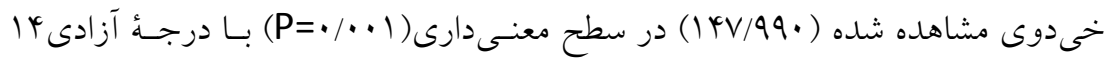

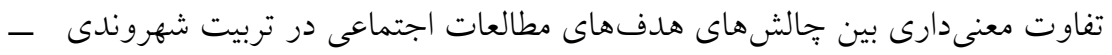

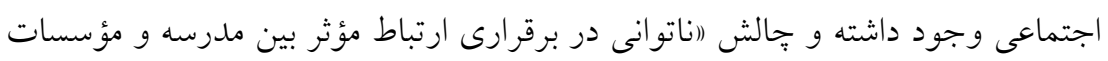

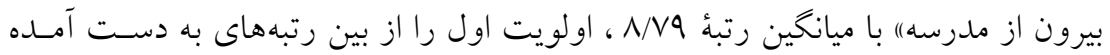
به خود اختصاص داده است.

سؤال يزووهشى Y: مهمترين جـالشهــاى محتــواى مطالعـات اجتمـاعى دورة ابتـدايى در تربيت شهروندى - اجتماعى كدامند؟ 


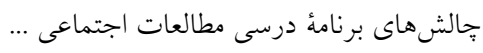

جدول r: نتايج آزمون فريدمن در خصوص اولويتبندى مقولههاى محتوا براساس ياسخ معلمان

\begin{tabular}{|c|c|c|c|c|c|c|}
\hline مقى مقد & 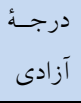 & تعداد & ريـانخين & 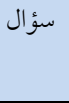 & مقولههاى هدفها & 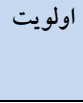 \\
\hline \multirow[t]{11}{*}{$0.19 \mathrm{MV}$} & \multirow[t]{11}{*}{1.} & \multirow[t]{11}{*}{$\mu r$} & $9 / 91$ & kr & 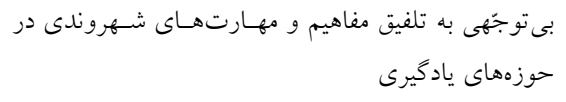 & 1 \\
\hline & & & $9 / \mu \mathrm{r}$ & v & 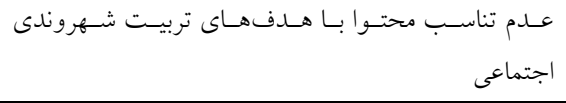 & r \\
\hline & & & $9 / \pi$. & 19 & عدم كاربردى بودن محتوا براى فراگيران & r \\
\hline & & & $9 / 19$ & or & 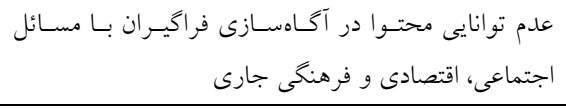 & r \\
\hline & & & $0 / 9 V^{4}$ & $r \cdot$ & عدم تناسب محتوا با ارزش هاى حاكم بر جامعه & 0 \\
\hline & & & $\Delta / 9 \vee$ & r & ساير دروس ارتباط مؤثر و مناسب محتواى مطالعات اجتماعى بـا & 9 \\
\hline & & & $0 / 9 r$ & rq & عدم تناسب محتوا با علايق و خواستههاى فراگيران & $\mathrm{v}$ \\
\hline & & & $0 / 91$ & ir & عدم تناسب محتوا با تجربيات دانش آموزان & $\wedge$ \\
\hline & & & $\Delta / V Q$ & ry & شهرم تناسب تصاوير انتخاب شـــ درمـتن بـا ارزشهــاى & 9 \\
\hline & & & $Q / \Delta \wedge$ & rl & عدم قابليّت اجر ايى فعّاليّت هاى كروهى درخواستى كتاب & 1. \\
\hline & & & $0 / 4 q$ & ry & 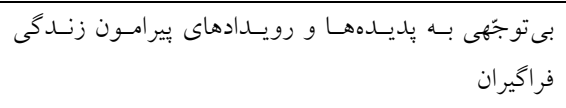 & 11 \\
\hline
\end{tabular}

جدول ب نتايج آزمون فريدمن براى اولويتبندى كويههاى مربوط به مؤلفهُ (إجالشهـاى محتو اى مطالعات اجتماعى دورة ابتدايى در تربيت شهروندى ــ اجتمـاعى" را براسـاس ميانخين رتبه هاى بهدست آمله نشان ميدهد. همانطور كه مشاهده مسى شــود مهــم تـرين جإلش محتواى مطالعات اجتماعى دورة ابتدايى در تربيت شهروندى - اجتماعى؛ مقولهُ

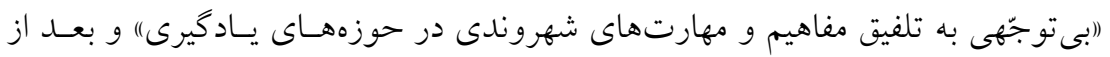

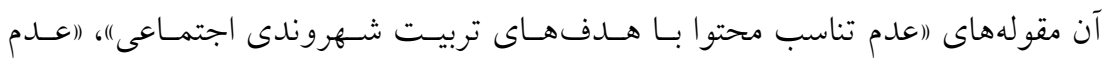
كاربردى بودن محتوا براى فراكيران) به ترتيب در اولويتهاى دوم و سوم قرار دارند. 
دو فصلنامهٔ نظريه و عمل در برنامة درسى، شماره V، سال جهارم، بهار و تابستان ه9r|

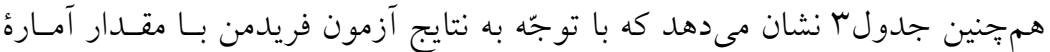

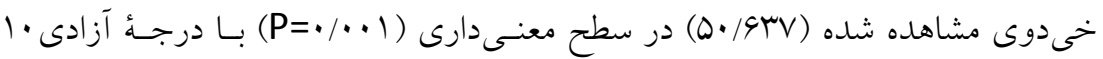

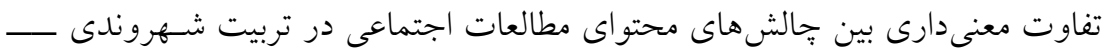

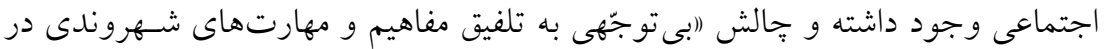

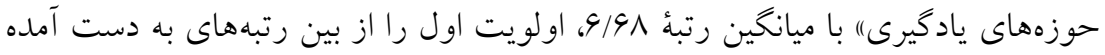
به خود اختصاص داده است.

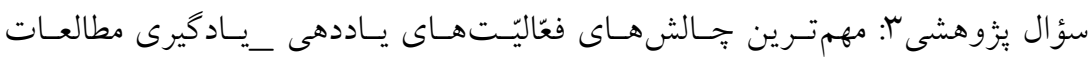

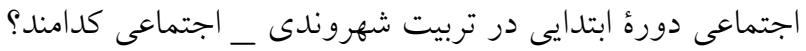

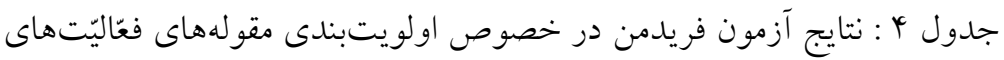

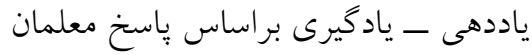

\begin{tabular}{|c|c|c|c|c|c|c|}
\hline مقدئسدار & 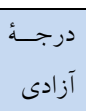 & ت تعداد & ميانخين & 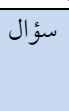 & مقولههاى هدف ها & اولويت \\
\hline \multirow[t]{8}{*}{ IrI/99T } & \multirow[t]{8}{*}{ V } & \multirow[t]{8}{*}{ MTV } & $0 / 79$ & $r$ & 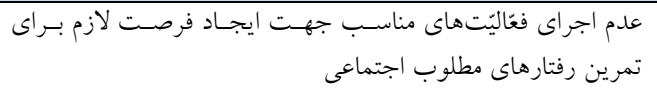 & 1 \\
\hline & & & $Y / A V$ & 1. & 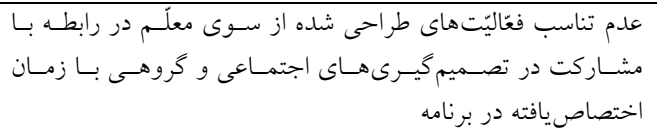 & $r$ \\
\hline & & & 1/99 & 10 & 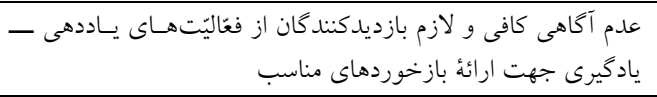 & $r$ \\
\hline & & & $4 / 09$ & 19 & 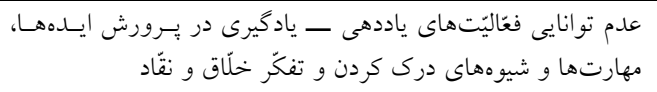 & 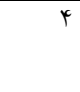 \\
\hline & & & $Y / Q \Lambda$ & $r$ & ساتوانى فعَّاليّت هاى انجام شده در ايجاد فرصت بحث و تبـادلنظـر & 0 \\
\hline & & & $F / Y q$ & 4 & بى توجّهى به فعَاليّت هاى يادكيرى خارج از محيط مدرسه & 9 \\
\hline & & & $4 / .9$ & TV & 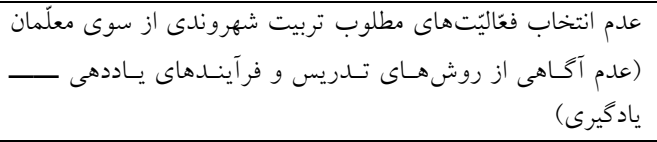 & V \\
\hline & & & $r / 91$ & rr & 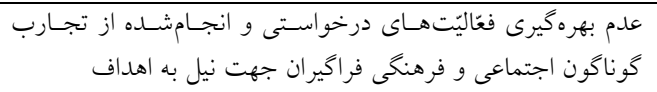 & $\wedge$ \\
\hline & & & & & سطح معنى دارى 1... - & \\
\hline
\end{tabular}


جالش هاى برنامة درسى مطالعات اجتماعى ...

جدول ع نتايج آزمون فريدمن براى اولويتبندى كويههاى مربوط به مؤلفهُ "(جـالش -

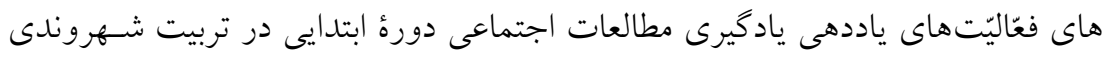

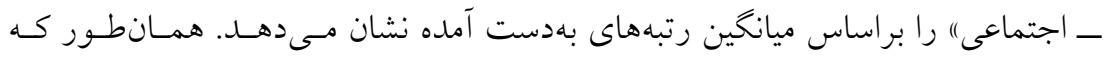

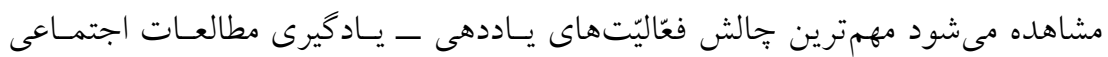

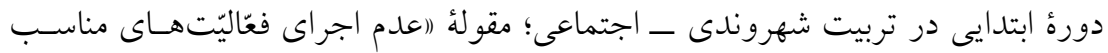

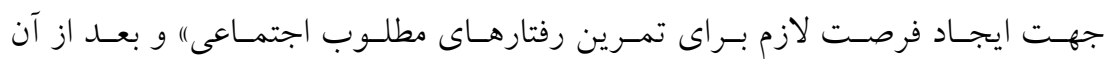

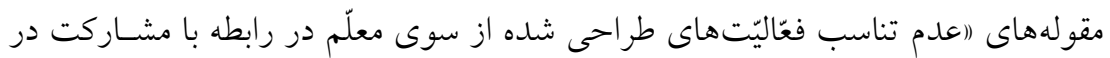

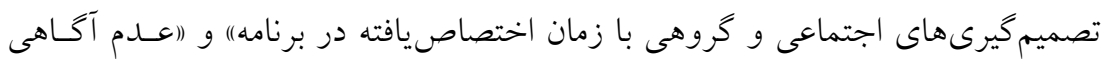

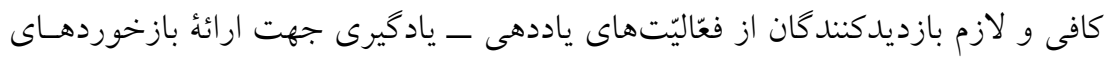
مناسب" به ترتيب در اولويتهاى دوم و سوم قرار دارند.

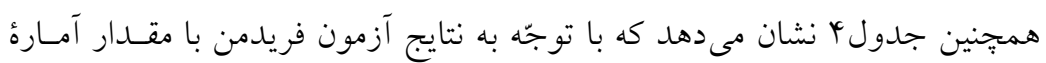

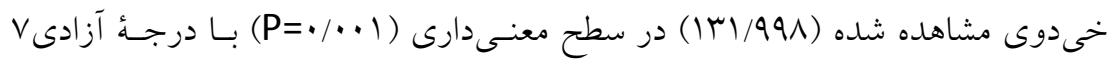

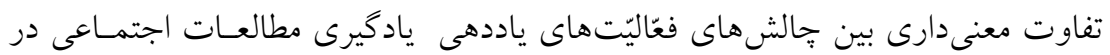

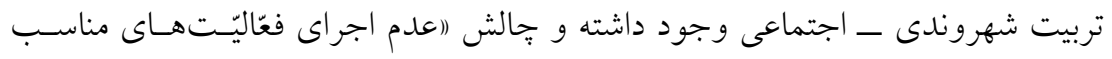

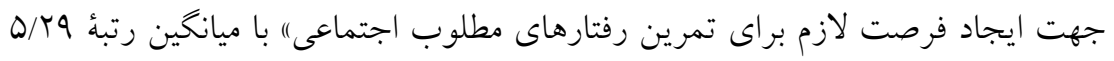

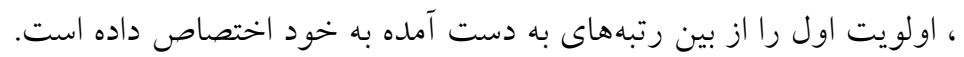

سؤال يززوهشى †: مهمترين جّالشهـاى ارزشـيابى مطالعـات اجتمـاعى دورة ابتـدايى در تربيت شهروندى ـ اجتماعى كدامند؟ 
جدوله : نتايج آزمون فريدمن در خصوص اولويتبندى مقولههاى ارزشيابى براساس ياسخ معلمان

\begin{tabular}{|c|c|c|c|c|c|c|}
\hline خـى مقدوار & 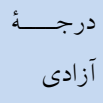 & تعداد & ميانخين & 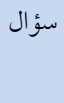 & مقولههاى هدفها & 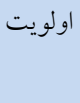 \\
\hline \multirow[t]{7}{*}{$9 T / 1 T q$} & \multirow[t]{7}{*}{4} & \multirow[t]{7}{*}{ rrv } & $y / 4 \varphi$ & ry & عدم توجّه به خلاقيّت و نو آورى فراگيران در ارزشيابى & 1 \\
\hline & & & $\uparrow / T \Lambda$ & IV & بىتوجّهى به حيطههاى سه كانهُ يادگيرى در ارزشيابى & r \\
\hline & & & 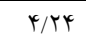 & if & عدم توجه به فعَّليّت هاى كروهى در ارزشيابى & r \\
\hline & & & $\psi / \cdot \wedge$ & $r_{\Lambda}$ & عدم اعمال ارزشيابى درتمام مراحل برنامه & r \\
\hline & & & $r / 94$ & 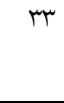 & 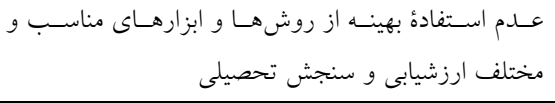 & 0 \\
\hline & & & $r / 9 V$ & 9 & عدم استفاده از انواع ارزشيابى & 9 \\
\hline & & & r/ro & r. & عدم اجرا يا عدم حضور در دورههاى علمى و موردنياز & $\checkmark$ \\
\hline & & & & 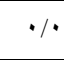 & سطح معنى دارى & \\
\hline
\end{tabular}

جدول ه نتايج آزمون فريدمن براى اولويتبندى كويههاى مربوط به مؤلفهُ (إجالشهاى ارزشيابى مطالعات اجتماعى دورهُ ابتدايى در تربيت شهروندى ـ اجتمـاعى" را براسـاس

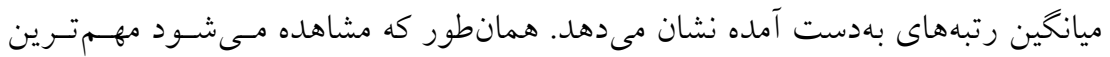
جالش ارزشيابى مطالعات اجتماعى دورهُ ابتدايى در تربيت شهروندى ـ اجتماعى؛ مقوله "(عدم توجّه به خلاقيّت و نوآورى فر اخيران در ارزشيابى" و بعد از آن مقولـههـاى (بسى -

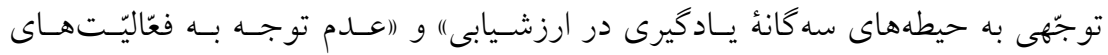
كروهى در ارزشيابى" به ترتيب در اولويتهاى دوم و سوم قرار دارند. هم جنين جدول ه نشان مىدهد كه با توجّه به نتايج آزمون فريدمن بـا مقـدار آمـارهُ

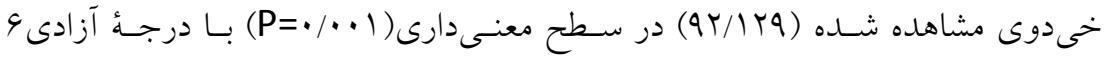
تفاوت معنى دارى بين جالش هاى ارزشيابى مطالعات اجتمـاعى در تربيـت شـهروندى اجتماعى وجود داشته و جّالش"(عدم توجّه به خلاقيّت و نوآورى فراخيران در ارزشيابى")

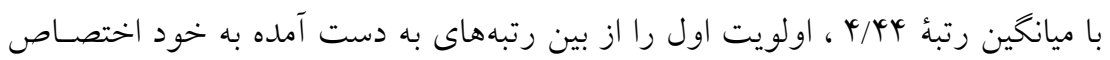
داده است. 
جالش هاى برنامة درسى مطالعات اجتماعى ...

سوال يُزوهشىه: آيا نظرات معلّمان زن و مرد در مورد جالشهاى برنامة درسى

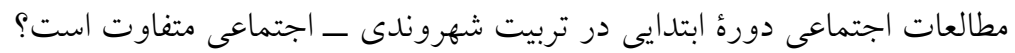

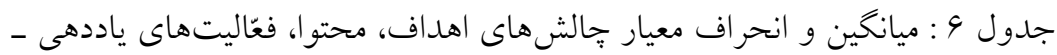

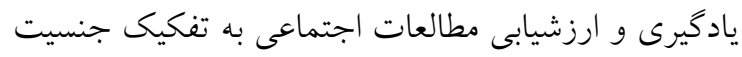

\begin{tabular}{|c|c|c|c|c|}
\hline \multicolumn{2}{|c|}{ مرد } & \multicolumn{2}{|c|}{ زن } & \multirow[t]{2}{*}{ متغيرها } \\
\hline انحراف معيار & ميانخين & انحر اف معيار & ميانخين & \\
\hline $1 r / 94$ & $0 Y / T q$ & $1 T / 99$ & $\Delta 1 / T \wedge$ & اهداف \\
\hline $1 \cdot / \mu \Lambda$ & $r \cdot / 4 r$ & $9 / \mu \wedge$ & MG/TG & محتو ا \\
\hline$V / r r$ & YN/A & $9 / 91$ & $T Y / Q T$ & فعَاليتهاى ياددهى \\
\hline $9 / 94$ & $r \phi / 4$. & $9 / 11$ & $r Y / Q$. & ارزشيابى \\
\hline
\end{tabular}

جدول 9، آمارهاى توصيفى دو جنس رادر مورد خالشهاى اهداف، محتـوا، فعّاليـت-

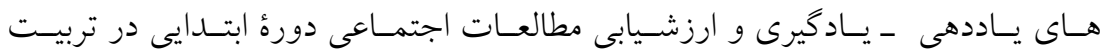

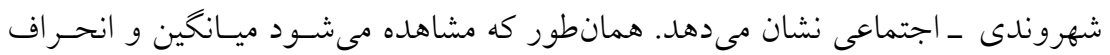

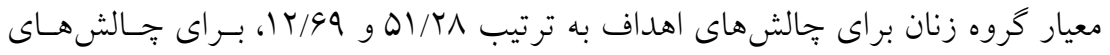
محتوا هو

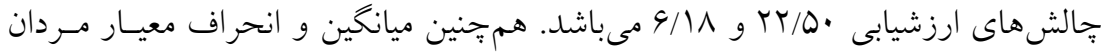

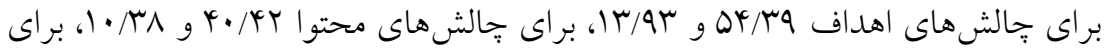

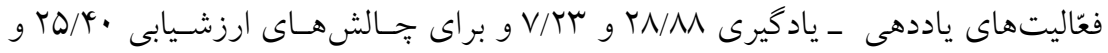
9/9r 
جدول V : نتايج t مستقل براى مقايسهُ دوكروه معلّمان زن و مرد در مورد جالشهاى اهداف، محتوا، فعّاليتهاى ياددهى - يادگيرى و ارزشيابى مطالعات اجتماعى دوره: ابتدايى در تربيت شهروندى - اجتماعى

\begin{tabular}{|c|c|c|c|c|c|}
\hline سطح معنى & خطاى معيار & ميانغينها & درجات & $\mathbf{T}$ & متغيرها \\
\hline .1 .9$. & 1/ATA & $r / l \cdot v$ & rTo & $1 / 9.9$ & اهداف \\
\hline 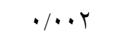 & 1/rar & $4 / 190$ & DTH & $r / \cdot V V$ & محتوا \\
\hline$\cdot / \cdot \cdot 1$ &.$/ 98 Y$ & $r / 994$ & סד & $4 / 111$ & فعّاليت ها ياددهى - يادگيرى \\
\hline.$/ \cdot 1$ & $\cdot / M M S$ & $r / 9.9$ & ס ס & r/TAK & ارزشيابى \\
\hline
\end{tabular}

با توجّه به جدول V، نتايج آزمون t نشان مىدهد كه بين نظـرات معلمـان زن و مسرد در

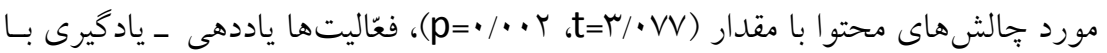
مقــدار ( معنادارى وجود دارد. امّا ميان نظرات اين دو گروه در مورد جالشهاى اهداف مطالعات اجتماعى در تربيت شهروندى ـ اجتماعى تفاوتى مشاهده نشد.

\section{بحث و نتيجه گيرى}

هدف يزّوهش حاضر شناسايى جالشهاى برنامة درسى مطالعات اجتماعى دورة ابتدايى در تربيت شهروندى ـ اجتماعى بود. يافتههاى يزوهش حاضر نشان مىدهد كه مهمترين

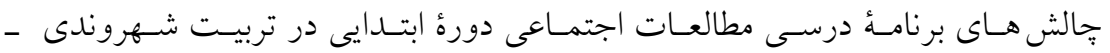
اجتماعى در عنصر هدف ها به ترتيب مقولههاى ناتوانى در برقـرارى ارتبـاط مـؤثر بـين مدرسه و مؤسسات بيرون از مدرسه، عدم توجِّهـ بـه شايسـتخى هــاى اجتمـاعى و عـدم هماهنگى هدف هاى تربيت شهروندى با نيازهاى اساسى دانش آموزان، در عنصـر محتـوا به ترتيب؛ مقولمهاى بىتوجّهى بـه تلفيق مفاهيم و مهارتهاى شهروندى در حـوزههـاى 
جالش هاى برنامة درسى مطالعات اجتماعى ... - ج

مختلف ياد گيرى، عدم تناسب محتو ابا هدفهاى تربيـت شـهروندى اجتمـاعى و عـدم كاربردى بودن محتو ابراى فراخيران، در عنصر فعاليتهاى ياددهى - يادگيرى به ترتيب؛ مقوله هاى عدم اجراى فعّاليّـتهـاى مناسـب جهـت ايجــاد فرصـت لازم بــراى تمــرين رفتارهاى مطلوب اجتماعى، عدم تناسب فعَاليّتهـاى طراحسى شــه از سـوى معلّـم در رابطه با مشاركت در تصميم گيرىهاى اجتماعى و گروهى بـا زمـان اختصـاص يافتـه در برنامه و عدم آكاهى كافى و لازم بازديدكنندگان از فعّاليّتهاى ياددهى - يادگيرى جهت ارائهُ بازخوردهاى مناسب و در عنصر ارزشيابى به ترتيـب، مقولـههـاى عـدم توجّهـه بـهـ خلاقيّت و نوآورى فراخيران، بىتوجّهى به حيطههاى سه گانهُ يادگيرى و عدم توجـهـ بـهـ

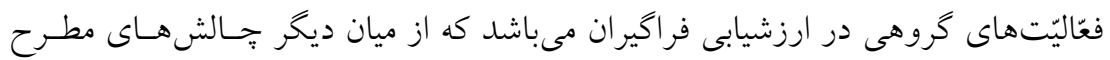
شده اولويتهاى بالاتر را به خود اختصاص دادهاند. لذا با توجه به جالشهـاى موجـود در زمينهُ عناصر برنامهُ درسى مطالعات اجتماعى، اخر نظام آموزشى بخواهد بـه رسـالت خودش در قبال اهداف اجتماعى تعليم و تربيت به درستى عمـل نمايســ بايسـ در حـوزه تربيت شهروندى برنامهريزى اصولى داشته باشـد. جنــان جـهـ در ايسن راسـا، هومانـا و

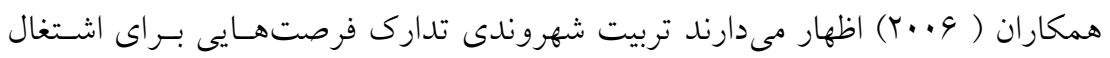
دانش آموزان در تجارب معنادار يادگيرى بوده و باعث تسُٔل رشد آنها به عنسوان افـراد متعهّد و فعّال اجتمـاعى و سياسـى مسى كـردد. ايسن موضـوعات (جــالشهـا) توسـط

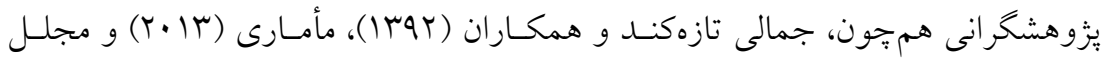
جوبقلو (INVV) هم مورد توجه قرار گرفته و با نتايج يافتههـاى آنهـا هــمخـوانى دارد. بخشى ديخر از يافتهها نشان مىدهد كه بين نظرات معلمان مرد و زن در مـورد جـالش هاى عناصر محتوا، فعاليتهاى ياددهى - يادگيرى و ارزشيابى تفاوت معنـادارى وجــود دارد. امّا ميان نظرات اين دو كروه در مورد جالشهاى عنصر اهداف مطالعات اجتمـاعى در تربيت شهروندى ــ اجتماعى تفاوتى مشاهده نشد. يافته مربوط به عنصـر هـدف، بـا

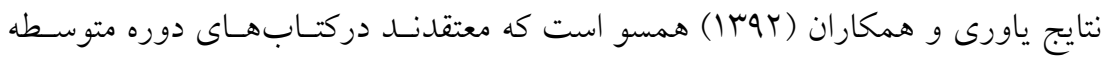
جايگاه بسيار كمرنخ توجّه اصولى و همهجانبه به آموزش و تربيت شـهروندى دانسش آموزان اين دوره به وضوح قابل مشاهده است. 


\section{بيشنهادها}

- در تعيين هدفهاى برنامة درسى مطالعات اجتماعى دورهٔ ابتدايى، برنامهريزان و كارشناسان برنامؤ درسى به ارتباط مؤثر ميان مدارس و مؤسسات بيرون از مدرسه به منظور همسوسازى رفتارهاى شهروندى توجَه نمايند.

- مر تدوين و سازماندهى برنامة درسى مطالعات اجتماعى ارزشهاى رايج جامعه را مدنظر قرارداده و به حيطههاى مختلف(دانش، توانش و نخرش) تربيت شهروندى توجَه نمايند. - مر تدوين محتواى مطالعات اجتماعى دوره ابتدايى ضمن توجه به اصل كاربردى بودن محتوا به تلفيق مفاهيم و مهارتهاى شهروندى ـ اجتماعى، با يديدهها و رويدادهاى زندگى خارج از مدرسه فراخيران اقدام نمايند. - جهت ارزيابى دقيقتر از آموختههاى دانشآموزان، از انواع روشها و ابزارهاى سنجش و اندازهيرى نظير آزمونهاى كتبى عملكردى، فهرست وارسى، جّى ليست، واقعهنخارى و ... استفاده نمايند و در ارزيابىهاى خود به حيطههاى مختلف يادكيرى(شناختى، عاطفى و رفتارى)، خلاقيت و نوآورى و كارهاى جمعى و و ورئي

$$
\text { مشاركتى (گروهى) توجه نمايند. }
$$

- به دليل كهنه بودن برنامهُ درسى مطالعات اجتماعى به خصوص در بايههاى جهارم و ينجم بهتر است به اصلاح و تجديدنظر اين برنامه اقدام گردد.

\section{منابع}

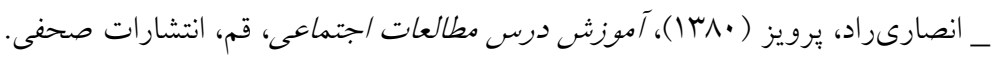
_ جمالى تازهكند، محمد؛ طالبز ادهنوبريان، محسن و ابوالقاسمى، محمود (IMYY)، تحليل جايشاه مؤلفه هاى تربيت شهروندى در محتواى برنامئ درسى علوم اجتماعى دورهُ متوسطه، ثئوهش در برنامهريزى درسى، سال دهم، دوره دوم، ش .1.

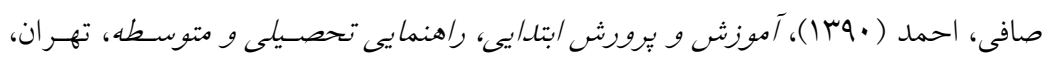
- فالكس، كيث ( •وبq)، شهرونالى، ترجمهُ محمدتقى دلفروز، تهران، كوير، جابٍ دوم. 


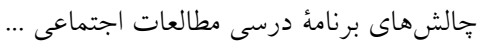

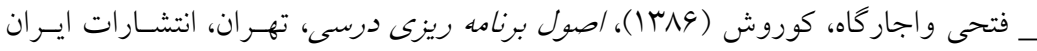

$$
\begin{aligned}
& \text { زمين. }
\end{aligned}
$$

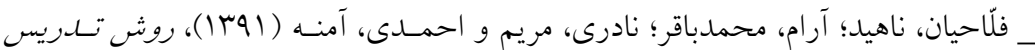

$$
\begin{aligned}
& \text { مطالعات اجتماعى، تهران، ادارهُ كل پاب و توزيع كتابهاى درسى. } \\
& \text { ــلتاش، عباس (INAV) }
\end{aligned}
$$

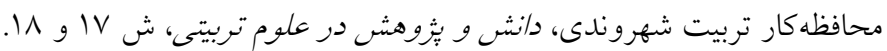

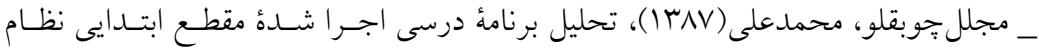

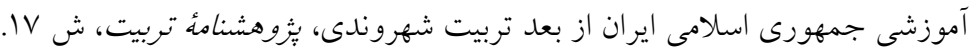

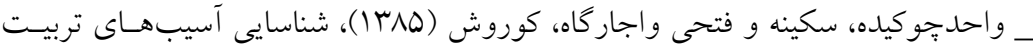

$$
\begin{aligned}
& \text { شهروندى در برنامة درسى ينهان، فصلنامة نوآورىهاى آموزشى، سال ينجم، ش IV. }
\end{aligned}
$$

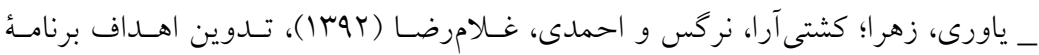

$$
\begin{aligned}
& \text { درسى دوره متوسطه با تأكيد بر تربيت شهروندى، فصلنامة علمى - ثئوهشى رهيافتى نسو } \\
& \text { در ملديريت آموزشى، سال جهارم، ش } 1 .
\end{aligned}
$$

-Cynthia, AT , Sung CP. (2008). Civic education, social justice and critical race theory In the sage handbook of education for citizenship and democracy. Los Angeles .

- Dee, Thomass. (2004). Are there Civic Return to Education? International Journal Educational Research. Vol. 88, No. 9-10.

- Fathi. K(2001 ). Required Characteristics for Good Citizenship .

- Homana, Gary and Carolyn Barber and Judith Toeney-purta. (2006).

Assesing school Citizenship Education Climate. University of Maryland. CIRCLE WORKING PAPER 48.

- Jorgenson, S. (2012). Global citizenship education(GCE) in post secondry institutions. University of Alberta. Journal global Citizenship, (2) 1.

- Liu, Meihui. (2001). The Development of Civic Values: Case study of Taiwan. International Journal of Education Research. Vol. 35. No. 1. 
دو فصلنامة نظريه و عمل در برنامة درسى، شماره V، سال جهارم، بهار و تابستان 94سا

- Maamari, S. A. (2013). The education of future citizents. Kuwait:

Carnegie.

- Miles, M .(2007). Innovation education: New York: teachers' College press.

- Niens, U. (2013). Citizenship Education in Divided societies. University of Ulster, Coleraine: Routledge. Retrieved from www.tand fonline. com.

- Parker, Walter. C. (2001). Education democratic citizen. Theory into practices. Columbus.

- Chambliss, JJ. (1996). Philosophy of education An Encyclopedia. New York. Gafland Publixhing, London.

- Quigley, Charls N. (2000). Global Trends in Civic Education. In www. Civiciced. Ory/Articles - Indonesia. html.

-Unesco.( 2015). Global Citizenship Education. France.-

- Sears. Alan and Y vonne Hebert. (2005). Citizenship Education. Canadian Education Association. In www. cea- ace. ca/ media/ en/ citizenship education.

- Solhaug,T. (2010) .Norwegian university of science and technology.

- summers, Jacqueline Y .(2002). A Proposal Model for Anchorage Adult

Civic Education. Unpuplished Master of Education Thesis. 